\section{FRANKENSTEIN 200 ANOS DEPOIS: ENTRE CIÊNCIA, VIDA E CORPO}

\author{
FRANKENSTEIN 200 YEARS LATER: BETWEEN SCIENCE, LIFE AND BODY
}

FRANKENSTEIN 200 AÑOS DESPUÉS: ENTRE CIENCIA, VIDA Y CUERPO

Fabio Zoboli, George Saliba Manske**, Hamilcar Silveira Dantas Júnior*
Palavras chave:

Ciência.

Corpo humano.

Vida.

Tecnologia.
Resumo: No ano de 2018 se comemorou o bicentenário da obra de Mary Shelley Frankenstein: o Prometeu moderno. Frankenstein é uma narrativa trágica que versa sobre a capacidade humana de dar vida "artificial" a um corpo pelo crivo da ciência e pelas astúcias da técnica. O presente ensaio tem como objetivo interpelar os usos do corpo pela ciência a partir da obra Frankenstein tensionando alguns litígios e pressupostos de caráter mítico/trágico que Mary Shelley suspende com sua obra. O escrito também disserta sobre as possibilidades de manipulação da natureza baseadas em conhecimentos de ordem molecular que direcionam para a construção de novas formas de Frankenstein e corpos, que abjeta costura de tecidos, próteses, acoplamentos e ciborguianismos, valorando a colonização interna da vida em si mesma.

\section{Keywords:}

Science.

Human Body.

Life.

Technology.

Abstract: 2018 marked the bicentenary of Mary Shelley's novel Frankenstein: The Modern Prometheus. Frankenstein is a tragic narrative that addresses the human capacity to provide "artificial life" to a body through science and the craftiness of technique. This work aims to address the uses of the body by science based on Frankenstein, stressing some mythical/tragic conflicts and assumptions that Shelley highlights in her work. The article also discusses the possibilities for manipulating nature based on molecular knowledge that guides the construction of new forms of Frankensteins and bodies, which rejects tissue stitching, prostheses, couplings and cyborgisms while valuing internal colonization of life itself.

Palabras clave: Ciencia. Cuerpo Humano. Vida. Tecnología.
Resumen: En el año 2018 se conmemoró el bicentenario de la obra de Mary Shelley "Frankenstein: el Prometeo moderno". Frankenstein es una narrativa trágica que versa sobre la capacidad humana de dar vida "artificial" a un cuerpo por el tamiz de la ciencia y por las astucias de la técnica. El presente ensayo tiene como objetivo interpelar los usos del cuerpo por la ciencia a partir de la obra de Frankenstein, tensando algunos litigios y presupuestos de carácter mítico/trágico que Mary Shelley suspende con su obra. El escrito también diserta sobre las posibilidades de manipulación de la naturaleza basadas en conocimientos de orden molecular que llevan hacia la construcción de nuevas formas de Frankenstein y cuerpos, en abyecta costura de tejidos, prótesis, acoplamientos y ciborguianismos, valorando la colonización interna de la vida en sí misma.
*Universidade Federal de Sergipe. Aracaju, SE, Brasil.

E-mail: zobolito@gmail.com; hamilcarj@ @otmail.com

**Universidade do Vale do Itajaí (UNIVALI). Itajaí, SC, Brasil. E-mail: gsmanske@yahoo.com.br

Recebido em: 04-06-2019 Aprovado em: 17-09-2019 Publicado em: 03-12-2019

DOI: https://doi.org/10.22456/1982-8918.93466 (c) (1) (8) Licence 


\section{INTRODUÇÃOO}

Em 2018 se comemorou os 200 anos da obra Frankenstein: o Prometeu moderno, escrita pela britânica Mary Shelley. $O$ conto narra a estória de Victor Frankenstein, um estudante de ciências naturais que, trancafiado em seu laboratório, constrói uma "criatura" a partir de retalhos de corpos mortos furtados das catacumbas de um cemitério. Victor dá forma à criatura, costurando as partes desses corpos, que ao final é animada pela aplicação de "uma centelha de vida na coisa inerte" (SHELLEY, 1999, p. 65).

A novela de Shelley gira em torno desse "monstro" gerado pelo Dr. Frankenstein que jamais foi nominado e tornou-se a representação em si mesmo, que leva o nome de seu criador: "o cientista". Frankenstein é um enredo trágico sobre a criação da vida artificial. Victor gera uma vida em seu laboratório e ao final essa "criatura" o mata - mata seu criador. Desta forma, a obra narra a problemática da ciência moderna como hybris' chamando atenção para seu caráter ameaçador.

Um conto que versa sobre um corpo criado pelo crivo da ciência e pelas astúcias da técnica não poderia ter outro subtítulo senão "o Prometeu moderno". Em seu romance, Mary faz alusão ao mito grego de Prometeu, que trata da inveja humana frente aos deuses por estes terem o poder não só de gerar a vida, mas também de interferir sobre ela, sobre sua manutenção e prolongamento - afinal, o corpo é o lugar da morte. Essa inveja é aliviada pelo furto do "fogo de Zeus", que dá ao homem a dádiva da técnica - poder de intervir na natureza. Prometeu e Frankenstein são assim arquétipos de um corpo que é território de experimentação e, no caso do "monstro" narrado por Mary Shelley, um corpo moderno, um corpo da ciência.

O presente ensaio tem como objetivo interpelar os usos do corpo pela ciência a partir da obra Frankenstein tensionando alguns litígios e pressupostos míticos/trágicos que Mary Shelley suspende com sua obra: em que medida Frankenstein nos faz refletir sobre as inquietações do corpo na modernidade? Por que o cientista não pôde dar nome a essa "criatura"? Por que Frankenstein é considerado um "monstro"? O que os "retalhos" com que a criatura foi gerada nos fazem pensar sobre os limites/fronteiras de um corpo atravessado pela ciência na modernidade? E mais: as possibilidades hodiernas de manipulação da natureza direcionam para a construção de novas formas de Frankenstein que abjeta costura de tecidos, próteses, acoplamentos, ciborguianismos para sobrepor-se, a partir de manipulações da vida em si mesma, em nível de informações moleculares, outros corpos (monstruosos!?)?

Para lograr o objetivo deste ensaio o texto é apresentado em três partes. Num primeiro momento disserta-se sobre Mary Shelley e a sua obra a fim de compreendermos o contexto em que foi escrita. Na segunda parte do escrito dissertamos sobre o corpo sob o viés da racionalidade científica tensionando-o com alguns argumentos do romance Frankenstein: 0 Prometeu moderno. Por fim, tecemos considerações alusivas às formas como os saberes biotecnológicos contemporâneos podem implicar não apenas outras produções de corpos e vida, mas, também, como isto afeta de forma ontológica a figura de Frankenstein.

1 A palavra grega hybris remete "a uma trama de ligações cujo denominador comum é a mistura de coisas de ordens distintas, da qual resulta algo excessivo (ou seu inverso, algo em falta" (MADEIRA, 2010, p.1). Nesta trama destaca-se a ligação com o termo "monstro", presente desde a mitologia grega até a ciência moderna. 


\section{MARY SHELLEY E A OBRA FRANKENSTEIN}

Entre os séculos XVIII e XIX, a Europa é impactada por ideias radicais nas esferas políticas, religiosas, literárias e filosóficas, porém nada tão fecundo quanto as orientações da nascente ciência, seu pensamento e método para o cotidiano social. Os ventos soprados pela "Declaração dos direitos do homem e do cidadão", a valorização dos indivíduos, a limitação da ação estatal à vontade geral, o ideário da Revolução Francesa sob as vestes iluministas passavam a orientar a vida social europeia.

Superar o obscurantismo religioso, ousar, como diria Kant, fazer uso da razão para julgar as ações dos homens tornaram-se a tônica desse momento. A esse ideário filosófico e político aliaram-se os experimentos de cunho científico, em substituição às artes místicas ou ocultistas como a alquimia, exigindo das universidades que se tornassem instituições acadêmicas balizadoras do "fazer científico". As experiências de cientistas como William Gilbert, Luigi Galvani, Alessandro Volta, Andrea Vesálio e Wiliam Harvey com o magnetismo, a eletricidade, a anatomia e fisiologia humanas foram fundamentais ao avanço da ciência e definição dos limites e fronteiras a ultrapassar, assim como os riscos dessas ultrapassagens.

Em meio a essa explosão de ideias e práticas, nasce, em 1797, Mary Wollstonecraft Godwin, filha de dois reconhecidos literatos: Richard Godwin, filósofo e escritor anarquista, e Mary Wollstonecraft, notória precursora do movimento feminista com seu livro $A$ vindication of the rights of women. Sua mãe advogava a emergência emancipatória das mulheres ante 0 patriarcado, assim como a limitação das ações estatais na vida privada das pessoas, ações estas que tão somente ratificavam a opressão masculina. Em ambiente tão fervilhante de ideias, era de se esperar ações rebeldes da jovem Mary, que, aos 16 anos de idade, fugiu de casa para se unir ao poeta Percy Bysshe Shelley, ainda que ele já fosse casado. Bysshe Shelley era um notório representante do romantismo inglês por conta de seus textos irreverentes e iconoclastas à política e instituições acadêmicas e religiosos. Mary passa a se chamar Mary Wollstonecraft Shelley e a conviver com os mais fecundos círculos literários da Europa (GUIMARÃES, 2018).

Mary e Percy Shelley, com a adesão da irmã adotiva de Mary, Claire Clairmont, iniciam em 1814 uma grande viagem pela Europa. Os textos dessa viagem revelavam vinculação do casal Shelley com o romantismo: a evocação da natureza, sua beleza, grandiosidade, vastidão e imponência. A natureza se situava nas obras românticas não como um cenário, mas como um personagem ativo, uma entidade viva e autônoma, capaz de subjugar os homens (EL MONSTRUO..., 2018). Nessa viagem, o casal Shelley conhece o famoso poeta George Gordon Byron, mais conhecido como Lorde Byron, tendo muitas aproximações com seu ideário romântico. Em fins de 1817, os Shelley passam uma temporada na casa de Lorde Byron na Suíça. Junto com John Polidori, os debates literários, as leituras de obras góticas de terror, além das críticas aos avanços produzidos ciência, acirram os ânimos em torno da produção de obras conjuntas. Lorde Byron lança um desafio ao grupo: produzirem uma autêntica história de terror. Esse desafio foi posto de lado, exceto pela jovem Shelley e por John Polidori, que, inquietos, buscaram dar vazão aos sentimentos da época, mas sem descurar da crítica ao contexto vigente. Seguindo a tradição da época, Polidori produziu uma obra fantasmagórica e sobrenatural, "adiantando-se oitenta anos ao Drácula de Bram Stoker, Polidori escreve El vampiro e assenta as bases da figura do chupa-sangue romântico" (EL MONSTRUO..., 2018, p. 17). 
Em direção contrária e em oposição ao estilo gótico e sua narrativa de sujeitos depravados, ligados ao sobrenatural, às artes ocultas e místicas, que habitavam lugares (geralmente castelos) sombrios e graças a suas maldades e atentados morais recebiam um castigo divino ao final dos romances, Mary Shelley elaborou o relato das desventuras do Dr. Victor Frankenstein, pontuadas pelas aspirações do Capitão Robert Walton. Saíam de cena os fantasmas, assombrações e vampiros para se buscar compreender as motivações psicológicas e sociais das personagens, a saber, o domínio do conhecimento científico e das suas fronteiras para alteração da realidade e reconhecimento social. O Dr. Frankenstein é o narrador principal da obra e será a inspiração para a personagem que abre o romance com uma narrativa epistolar: o Capitão Robert Walton. Walton busca ser o primeiro a contornar o Polo Norte enfrentando toda a sorte de adversidades. A narrativa de Frankenstein o fará repensar seriamente dos perigos de enfrentar tão abertamente a Mãe Natureza.

A Natureza, a mãe criadora, viva e ecológica do movimento romântico seria afrontada pela ação do Dr. Frankenstein: dar um fluido vital a uma criatura construída por restos mortais humanos. A obsessão de Victor Frankenstein em dominar a relação vida e morte desvela 0 desrespeito às leis de natureza, gera um desequilíbrio na vida social e desencadeia a tragédia.

Para Manguel (2018), algumas referências foram fundamentais a Mary Shelley na construção de sua obra máxima. "A balada do velho marinheiro", publicada em 1798 por Samuel Taylor Coleridge, narra as desventuras da tripulação de um barco assombrado por fantasmas e toda a sorte de infortúnios. Essa maldição se deu por conta da ação de um marinheiro que havia matado um albatroz, uma ave compreendida como de bom agouro. A Natureza se vinga dessa afronta a uma de suas espécies reais com o envio dos espectros da Morte e da Morte em Vida que mata todos os tripulantes à exceção do velho marinheiro assassino que carregará a culpa por toda a eternidade. Há um claro vínculo com a maldição que sobrevirá a toda a tripulação do Capitão Robert Walton caso ele continue a sua empreitada desafiadora.

De modo análogo Victor Frankenstein afrontou as leis da natureza ao gerar uma vida, em seguida ao renegar sua criação (seu filho), ao negar-lhe uma companheira, ao condenálo à solidão, à não vida. Essa percepção crítica está nas palavras da própria criatura quando repudia a sociedade e a geração da maldade em si:

Acredita-me, Frankenstein, eu era bom. Minha alma estava cheia de amor pela humanidade; mas não estou só, miseravelmente só? Tu, meu criador, me detestas; que posso, pois, esperar de teus semelhantes, que nada me devem? Eles me desprezam e me odeiam. [...] Se toda a humanidade soubesse da minha existência, faria como tu, armar-se-ia para minha destruição. Não devo, pois, odiar aqueles que me detestam? Não terei contemplação para com meus inimigos. Eu sou um miserável, e eles devem compartilhar da minha desgraça (SHELLEY, 1999, p. 116).

Essa afronta ao equilíbrio da natureza produz a morte de todas as mulheres que cercam Victor Frankenstein. As mortes são executadas pela criatura, mas, no entendimento de Shelley, são causadas pelo egoísmo masculino em querer dominar tudo, inclusive o que não lhe é natural. Nesse contexto, Victor Frankenstein não só não consegue criar vida, mas as destrói!

Nesse movimento, Mary Shelley produz também uma crítica feminina à ciência e sua lógica patriarcal, invasiva à natureza que, todavia, é indomável em sua essência criadora. Em contrapartida, Manguel (2018) afirma que Shelley, ao advogar a influência de John Milton e seu poema Paraíso perdido, de 1667, exalta seu caráter patriarcal e misógino, afinal a criatura não 
se identificaria com Adão (apesar de se comparar a ele ante seu criador), mas com Eva, posto que nasce sem história (vinda de um pedaço do homem, a costela), peca por buscar o saber e desencadeia toda a tragédia por comer do fruto proibido.

Enfim, a escrita de Frankenstein ou o Prometeu moderno por Mary Shelley 1818, na descrição dos infortúnios do Dr. Frankenstein, quais sejam, criar um ser horrendo com retalhos de cadáveres, abandonar sua própria criação, assistir à vingança violenta da criatura e a destruição de sua família, por fim, lançar-se à caça do monstro, torna-se um marco literário do século XIX. Mary Shelley, intencionalmente ou não, assentou os fundamentos da literatura de ficção científica: a desconfiança quanto à neutralidade, segurança e boas intenções da ciência, bem como os perigos da humanidade por avançar em terrenos que não são de sua alçada. Ao denominar Frankenstein de Prometeu moderno, Shelley sinalizava que a reação da Natureza, ou dos deuses, seria implacável pela ousadia de subversão a ordem natural.

\section{FRANKENSTEIN, CORPO E MODERNIDADE}

O romance Frankenstein faz menção a Prometeu ${ }^{2}$ em seu subtítulo. Ao trazer a metáfora de Prometeu para seu romance, Mary Shelley quer chamar a atenção para o domínio da natureza por meio da técnica e da ciência. O mito conta que Zeus solicitou aos irmãos Prometeu ${ }^{3}$ e Epimeteu que fizessem os animais e a espécie humana. Afoito, Epimeteu começa a empreitada, no entanto, ao fazer os animais, esquece de guardar os atributos para fazer do homem um ser completo. Quando chega a vez de fazer o homem, Epimeteu se dá conta que fez uso de quase todo material disponível. Aterrorizado, pede ajuda a seu irmão Prometeu, que vai até Zeus e the rouba o fogo para resolver o problema e assim corrigir tal incompletude. 0 fogo de Zeus é a metáfora da técnica e da ciência que instrumentaliza a espécie humana a conseguir por si aquilo que doravante suplicava aos deuses.

Porém, Zeus se enfurece com o delito de Prometeu e como castigo o acorrenta a uma rocha onde tem seu fígado eternamente devorado por uma ave de rapina. Durante a noite 0 fígado de Prometeu se regenera e no outro dia a ave volta a comê-lo. Além de Prometeu, Zeus providencia um castigo para os homens e envia à Terra a primeira das mulheres: Pandora 4 . Ela traz para Epimeteu uma caixa onde estão guardados os males que Zeus reservou aos mortais. Frankenstein representa - há 200 anos - o limiar do porvir das realizações médicas, ele fala do medo nascente frente ao desconhecido, Frankenstein fala da abertura da caixa de Pandora, que é aqui o corpo humano (LE BRETON, 2005). Talvez o subtítulo de Frankenstein merecesse alusão não somente a Prometeu, mas também a Pandora. Pandora traz em sua caixa não apenas o mal, mas a esperança, que pode ser a mesma coisa, pois acreditamos que o humano só irá sucumbir às suas próprias mazelas na medida em que perder as esperanças de que pode ser Deus.

Um dos marcos da modernidade é a substituição da verdade religiosa como legado divino para os critérios da ciência como paradigma. A revolução iluminista procurou, como

\footnotetext{
20 mito grego de "Prometeu, Odisseu e Pandora" juntamente com o mito de Ulisses - narrado em A odisseia por Homero - são os dois mitos fundantes da modernidade.

3 A etimologia do nome Prometeu provém de pró, antes, e manthánein, aprender, saber, perceber, ver, significa exatamente 0 que 0 latim denomina prudens, de prouidens, o prudente, o "pre-vidente", o que percebe de antemão - o oposto de Epimeteu (BRANDÃO, 1986, p. 166). Por isso Prometeu é o símbolo da ciência na medida em que a ciência projeta - vê antes de fazer - a partir de conhecimentos. Epimeteu simboliza aquele que medita/pensa demasiado tarde.

4 Pandora provém, em grego, de pân, todo, e dôron, presente, e significaria, assim, um dom, um presente dôron de todos pánton os deuses
} (BRANDÃO, 1986, p. 168). 
vetor da modernidade, tirar o corpo das mãos de Deus e colocá-lo na mesa para dissecá-lo e desmontá-lo em partes via postura da ciência metódica. E cada vez mais na modernidade a ciência vai sendo aceita pela sua capacidade de produzir tecnologia, "assim, a tecnologia passa a ser entendida como a verdade pragmática da ciência" (LEFREVE; LEFREVE, 2009, p.17). O ensaio leva em consideração essa premissa, pois entende que uma das características da modernidade é o caráter profético da ciência - a apelação ao científico. Um dos maiores perigos da fetichização da tecnologia é quando o produto da ciência acaba se transformando em objeto de fé, afinal o maior legado que a ciência vem deixando na modernidade não provém necessariamente de seus produtos tecnológicos, mas, sim, da forma com que ela mesma vem ocupando um espaço mítico (SARTI, 2012).

Shelley é irônica e providencial quando opta por não dar nome à remendada e malsucedida criação do Dr. Frankenstein, que durante a trama ela chama de "monstro", "criatura", "desgraçado", "abominável". Assim, pode-se pensar que a hybris científica está ligada à irresponsabilidade de um pai que nem sequer foi digno de colocar um nome para seu filho criatura (SARTI, 2012). Por tal motivo, Frankenstein figura como uma obra de terror, afinal, sua natureza é ambígua e por assumir tal condição provoca repulsa, horror e medo. Frankenstein é uma crítica à modernidade, uma crítica aos "feiticeiros" das ciências que manipulam o corpo. "[...] Frankenstein não denomina o monstro, mas o cientista" (COLI, 2003, p. 301): Frankenstein não é o monstro, Frankenstein é o cientista criador de monstros.

Victor não nomeia seu "monstro", pois ele pertence à esfera do inclassificável, porque ele está fora do sistema simbólico e, portanto, da inteligibilidade que define as fronteiras entre as categorias do pensamento, elas são ambíguas e provocam uma mistura de repulsa e medo (LE BRETON, 2005). Por ele ser uma aberração, entra na categoria da monstruosidade sob dois aspectos: 0 do monstrum, que indica um sentido de algo a ser mostrado e exibido; e o de monestrun, que tem uma conotação ligada à advertência, à enunciação e à prevenção (MADEIRA, 2010). Assim, retomamos o pressuposto de que Frankenstein foi escrito por Mary a partir do argumento da crítica à desconfiança profunda do avanço da ciência alertando sobre o perigo frente ao desejo humano de ser deus, de controlar a natureza e produzir a vida artificialmente.

Por isso a autora menciona no prefácio de sua obra que sua motivação foi a de produzir "uma história que falasse aos misteriosos medos de nossa natureza e despertasse um espantoso horror - capaz de fazer o leitor olhar em torno amedrontado, capaz de gelar o seu sangue e acelerar os batimentos do seu coração" (SHELLEY, 1999, p. 8). Ou seja, estão explícitos os sentidos do monstro sob o viés tanto do monstrum como do monestrun.

Sob esta mirada podemos pensar na ciência moderna também como estratégia política de fabricação de corpos. Shelley traz a cena em seu romance um corpo do começo da modernidade, um corpo cuja ideia é de uma máquina divorciada de uma consciência subjetiva que não se identifica com ele (SARTI, 2012). Um corpo físico pautado na biologização cadavérico-anatômica, porém, essa biologia é também política, pois transcende a dimensão do cadáver. Ela é uma anatomia política na medida em que a biologia passa a ser um imperativo, mais que um método, uma moral, mais que uma teoria (CANGUILHEM, 1976).

O corpo é um resíduo sob o qual a ciência moderna investiu via instituições com a finalidade de controlar o indivíduo (corpo individual) e as populações (corpo social): "El cuerpo fue objeto de representaciones dirigidas a construir a partir de él un proyeto colectivo" (VALLEJO; MIRANDA, 2007, p. 18). Os corpos foram projetados para serem produzidos em 
série, servindo de metáfora do sonho/pesadelo da ciência moderna em criar corpos perfeitos através do aperfeiçoamento da raça humana - eugenia. Mas a perfeição tem seu preço. "Só aquilo que é perfeito se torna digno desse mundo. Legitima-se dessa maneira a supressão do resto" (COLI, 2003, p. 313).

A ciência criou políticas que normatizaram e normalizaram os usos do corpo e da população. Com a modernidade nasceu também o direito de exterminar o outro legitimado pela racionalidade da ciência que autoriza a morte via construção da fobia do outro. A modernidade criou políticas que justificaram o apagamento de corpos sob a certificação da ciência - a modernidade fez "sombras" com suas "luzes" (ZOBOLI, 2018). Ao criar o normal a ciência cria também o abjeto, o monstro, os "Frankensteins" que não cabem nas taxionomias metafísicas da norma. A modernidade cria a biopolítica e a tanatopolítica.

Esta relação histórica longa, de articulação entre os termos híbrido e monstro, que passa pela cada vez maior mediação da ciência ao longo dos séculos (deixando para trás mitologias, superstições e crenças religiosas), indica, portanto, que um primeiro passo para a integração do anômalo, e portanto do híbrido, se traduz na naturalização e banalização (MADEIRA, 2010, p. 2)

Outra questão que queremos trazer ao ensaio tem relação com a "centelha de vida" que animou o corpo de Frankenstein. A centelha metaforiza o sopro divino, também metaforiza o fogo de Prometeu. É a ânima, a alma que anima, é o código imaterial que dá vida à matéria. Com a decodificação genética nos meados da década de 1990, o gene passa a assumir a metáfora da centelha de vida com a replicação do humano via clonagem. Com a decifração do DNA - o texto bioquímico que codifica o indivíduo - o corpo passa a ser visto como informação armazenada: chip.

O destino dos homens como máquinas, contudo, estava finalmente inscrito em seus órgãos. Hoje, porém, o panorama mudou: a ordem mecânica que regia inexoravelmente o mundo de acordo com as leis física newtonianas foi desacreditada; o homem e a vida clamam por novas fundamentações. 0 destino dos seres humanos como feixes de informação parece ter mudado de lócus: agora está inscrito nos genes. A mutação metafórica não é tão sutil como parece, e suas implicações podem ser tão vastas (ou tão ínfimas) quanto o próprio homem (SIBILIA, 2002, p. 74).

As condições aludidas por Sibilia (2002) advogam se não uma mudança, um deslocamento das promessas e feitos da modernidade, calcadas em práticas, técnicas e pressupostos da ciência, para outro viés, qual seja, novas formas de fundamentação que abarcam outras possibilidades de ser humano, e no caso deste ensaio, outros Frankensteins. Nesse ínterim surgem manipulações sobre o corpo e a vida que se deslocam da vertente moderna de ciência, de manipulação do corpo via processos de construção e reconstrução de forma molar, para uma vertente pós-moderna de fabricação de corpos, situada e sitiada pelos saberes de ordem biotecnológica e de molecularização da vida. Tais desdobramentos sugerem outras formas compreensão de práticas prometeicas.

\section{UM FRANKENSTEIN NÃO TÃO MONSTRUOSO ASSIM?}

As produções no campo das ciências vinculadas à vida têm trazido de forma ampla inúmeras modificações nos modos de compreensão do ser humano, alterando, inclusive, 
sua ontologia, isso porque, concordando com Rose (2001), o ser humano é aquele tipo de criatura cuja ontologia é histórica. Desse modo, ao longo dos processos históricos e sociais que medeiam os seres humanos, aludimos que atualmente temos novas condições de produção da vida, e, sobretudo, dos corpos, o que implica a abertura de outras proposições epistemológicas para uma compreensão do Frankenstein.

Advogamos que as Ciências da Vida, sobretudo as biotecnologias, têm possibilitado a criação de imaginários relativos à ampliação dos potenciais humanos, subjugando a constituição própria da natureza à ciência, na direção de uma colonização da vida e dos corpos pelos saberes científicos por um viés distinto daqueles de séculos atrás (ROSE, 2013; RABINOW, 1999). Embora esse aspecto não seja de todo novo, na medida em que a ciência moderna já havia transitado por esse caminho, afirmamos que o modo como isso se apresenta na atualidade é diverso de como ocorrera no período da ficção de Mary Shelley, especialmente pelas técnicas e modos de compreensão do que vem a ser a vida.

Os aspectos contemporâneos das ciências em suas promessas de prolongamento da capacidade vital se materializam para além do campo científico e permeiam diferentes espaços da cultura. A Declaração de Transumanidade sitiada na página de uma organização internacional sem fins lucrativos como a Humanity+, que busca em relação à vida "não limitar seus desafios, mas desafiar seus limites" através do uso das tecnologias, a fim de ampliar as capacidades humanas, estas limitadas pela própria natureza do homem, é a materialidade cultural das promessas desses novos horizontes biotecnológicos. Tal como referido em seção anterior sobre a tentativa de criação da vida por Frankenstein, baseada no mito prometeico, as condições contemporâneas permitem direcionar a produção de vida e corpos numa perspectiva fáustica ${ }^{5}$, na medida em que buscam não apenas a fabricação da vida, mas sua eternização, baseadas nas biociências contemporâneas (SIBILIA, 2002). Além do mais, tal perspectiva pode ser tomada enquanto uma utopia pós-moderna, que "assume o lugar das antigas grandes narrativas para prometer amanhãs adoráveis, e até mesmo a imortalidade" (LE BRETON, 2012, p. 28-29).

Cabe ressaltar que esses deslocamentos das formas de compreensão da vida pelas biociências ocorrem, sobretudo, a partir do campo da genética. Os conhecimentos e, em especial, as técnicas de transformação da vida a partir de saberes genéticos permeiam o campo das biotecnologias desde meados dos anos 1990, quando já se apontava para a emergência de um ramo que dominaria os investimentos, as pesquisas, as atividades econômicas e cientificas e, inclusive, o imaginário social, a saber, a engenharia genética com ênfase na clonagem de seres vivos e no código genômico. O que está em pauta nesses processos é a centralidade do genoma enquanto principal vetor da descoberta e colonização interna da vida.

É necessário dizer que a forma de compreensão baseada na genética não vem a se sobrepor de todo modo às formas de manipulação do corpo e da vida baseadas em preceitos tradicionais da modernidade. Além do mais, ressaltamos que figuras híbridas também são destacadas em produções culturais e epistemológicas tais como o emblemático RoboCop ${ }^{6}$, que traduz a articulação das tecnologias então existentes nos anos 1970 e 1980 nas transformações corporais em nível visível. Um ciborgue tal como o RoboCop incorpora a materialização das tecnologias de aumento das capacidades humanas em nível 'molar', ou seja, em nível visto a

5 Fausto é um personagem mítico de tradição germânica que possui "vontade de crescimento infinito pelo desejo de superar suas próprias possibilidades", que em pacto com o diabo busca uma apropriação ilimitada da natureza com vistas à imortalidade (SIBILIA, 2002, 43).

6 "RoboCop" é um personagem ciborgue força da lei que ficou mundialmente conhecido pelo filme que leva seu nome: RoboCop (1987). 
"olho nu". Este protótipo de corpo já se difere daquele de Shelley, na medida em que faz uso de suportes mecânicos e robotizados para, se não criação da vida, sua salvação e ampliação.

No entanto, as condições atuais se distinguem fortemente tanto desta produção ciborguiana do RoboCop como, também, da produção de corpos e vida tal como de Frankenstein. As tecnologias sobre a vida têm atuado não do nível externo para interno; ou como formas de acoplar e costurar pedaços; e ainda, de enxertar algo no corpo e na vida, seja para criar, salvar ou potencializar. Pelo contrário. As tecnologias da vida hoje se encontram "no nível mesmo da própria vida" (ROSE, 2013), se apresentam como "políticas da vida em si mesma", atuam nos níveis de vitalidade enquanto 'gene'; como informação não mais materializada em peles, tecidos ou partes mecânicas, mas lá mesmo onde a vida se traduz em códigos binários alocados em enunciados passíveis de registros computacionais (ROSE, 2013; SIBILIA, 2002; RABINOW, 1999). Em outras palavras, corpos e vida se diluíram em formas moleculares de tradução e existência, em tecnologias digitais. Alterações genéticas, alelos, cromossomos, fertilização in vitro, armazenamento de memória em HDs externos, células tronco, órgãos 3D, bancos de neomortos, bioempório ${ }^{7}$ conformam esse novo cenário. E é nesse contexto que procuramos problematizar qual o espaço de produção de um novo Frankenstein. Caso existisse na atualidade, permeado por essas condições científicas e tecnológicas da vida e dos corpos, seria Frankenstein assim tão monstruoso?

Advogamos a ideia de que já está aqui e agora conosco. Diluído de forma molecular de modo a não percebermos. E obviamente, isto se dá pela nossa marcação epistemológica ainda moderna de compreensão e percepção de mundo, calcada no visível. Não vemos corpos manipulados pelas biotecnologias de ordem molecular como estranhos e abjetos, simplesmente pelo fato de não os vermos (a "olho nu"). Como afirma Le Breton (2012, p. 26), as intervenções terapêuticas não mais "provocam objeções; elas se integram num longo processo de restauração e engenhosidade da medicina. Algumas pessoas idosas, doentes ou portadoras de algumas deficiências são suas pioneiras, mesmo sem sabê-las". Entrementes, para além da ordem terapêutica de recuperação, caminhamos na direção do uso de tais possibilidades biotecnológicas para 0 aumento das potencialidades humanas não mais na ordem de reparação ou recuperação de um estado corporal falho ou anormal, mas, sim, na direção de uma ordem do incremento humano tal como advoga a Transumanidade.

Rose (2013) argumenta que temos experimentado formas agenciadas de vida a partir de interesses do biocapital, centradas na molecularização da vida e, consequentemente, otimização dos corpos, enquanto produtos de uma bioética de consumo do corpo em si mesmo. Assim, a vida e os corpos não estão mais sujeitos naturalmente às transformações por parte da ciência e tecnologias, ao contrário, a própria natureza dos corpos está sob construção 0 que está em pauta são as formas de produção da noção mesma de vida, de uma artificialidade da natureza, e mais, talvez, de um não lugar para noção tradicional de corpo, vida e natureza, tal como promulgada em diferentes vertentes da modernidade. Nesse ínterim, a produção de um Frankenstein não se dá pela costura de tecidos e pedações rijos de cadáveres, à luz de um sopro ou centelha que gere vida; tampouco pela ampliação das capacidades por acoplamentos mecânicos. O que está em voga é a fabricação da vida onde ela "realmente" reside e pode ser descrita, a saber, as informações genéticas e digitais. Aqui, se fabricam tecidos. Fabricam-se

\footnotetext{
7 Para melhor compreensão dos termos "neomortos" e "bioempório", vide Le Breton (2005) A síndrome de Frankenstein

8 Para uma discussão mais aprofundada destes deslocamentos em formas de sociabilidade vide Rabinow (2002) Artificialidade e iluminismo: da sociobiologia à biossociabilidade.
} 
corpos. Produzem-se vidas. E não mais de forma abjeta e monstruosa, mas quiçá, à mercê do interesse estético e de incremento de potências de seus clientes. O Frankenstein pós-moderno não causa medo, terror ou assombra (ao menos no plano das aparências...).

\section{CONSIDERAÇÕES FINAIS}

Uma das possíveis leituras que podemos fazer 200 anos depois de Frankenstein é a leitura mítica e trágica das promessas da ciência para com o corpo. O corpo atravessado pela ciência e pela técnica ainda não dá conta de sua proposição de superação. Em meio às sombras da modernidade visualizamos os monestrun advertindo que a ciência prende cada vez mais 0 corpo aos mitos que ela própria cria, mas que não dá conta de sua condição trágica. Ou seja, nos parece que a condição trágica do corpo frente à ciência e à técnica parece ser insuperável. Nesse sentido, ciência e mito na modernidade estabelecem uma luta contra o caráter trágico dos mitos de fundação da humanidade no sentido dos artifícios do logos científico pautados no monstro e no híbrido que excedem os limites da razão atual, de uma ciência ainda trágica e cheia de limites - artesanal, experimental e incerta em muitos aspectos. Contudo, essa sinergia moderna entre mito e logos ainda parece esbarrar nos signos do trágico. Continuamos presos às correntes de Prometeu. Cabe ao homem assumir que o "fogo" que roubou de Zeus agora também é seu, e, portanto, precisa se responsabilizar pelas suas obras. Se responsabilizar por elas significa sucumbir à sua fetichização e argumentá-la a partir de uma política pautada para além da sua mercantilização.

Entrementes, em coexistência com a concepção prometeica de corpos, vislumbramos um deslocamento para uma perspectiva fáustica, que intenta superar os limites da natureza do homem e, através das tecnociências biomoleculares, aludir uma nova condição ontológica calcada na ideia de infinitude da vida. Tais pressupostos nos permitem pensar em outras condições de corpos e Frankenstein, incluindo outra ontologia humana, mas que, de modo semelhante à intenção prometeica, ainda tem em suspensão e suspeição as condições trágicas da existência humana abordadas na obra de Mary Shelley.

\section{REFERÊNCIAS}

BRANDÃO, Junito de Souza. Mitologia Grega. Petrópolis, RJ: Vozes, 1986. v.1.

CANGUILHEM, Georges. El conocimiento de la vida. Barcelona: Anagrama. 1976.

COLI, Jorge. O sonho de Frankenstein. In: NOVAES, Adauto (org.). 0 homem-máquina: a ciência manipula o corpo. São Paulo: Companhia das letras, 2003. p. 299-316.

EL MONSTRUO de Frankenstein. Cuadernos de la BN, n. 11, p. 6-11, jun./jul. 2018.

GUIMARÃES, Armando Rui. Mary Shelley: vida e obra. In: ARAÚJO, Alberto Filipe; ALMEIDA, Rogério; BECCARI, Marcos. 0 mito de Frankenstein: imaginário e educação. São Paulo: 
LE BRETON, David. Individualização do corpo e tecnologias contemporâneas. In: COUTO, Edvaldo; GOELLNER, Silvana V. (orgs.). 0 triunfo do corpo: polêmicas contemporâneas. Petrópolis, RJ: Vozes, 2012. p. 15-32.

LE BRETON, David. A síndrome de Frankenstein. In: SANT'ANNA, Denise Bernuzzi. Políticas do corpo. 2 ed. São Paulo: Estação Liberdade, 2005. p. 49-68.

LEFREVE; Fernando; LEFREVE, Ana Maria Cavalcanti. 0 corpo e seus senhores: homem, mercado e ciência: sujeitos em disputa pela posse do corpo e da mente humana. Rio de Janeiro: Vieira \& Lent, 2009.

MADEIRA, Cláudia. Híbrido: do mito ao paradigma invasor? Lisboa: Mundos Sociais, 2010.

MANGUEL, Alberto. Prólogo: El monstruo de Frankenstein. In: CAPANNA, Pablo et al. El monstruo de Frankenstein. Buenos Aires: Biblioteca Nacional, 2018. p. 7-9.

RABINOW, Paul. Artificialidade e iluminismo: da sociobiologia à biossociabilidade In: RABINOW, Paul. Antropologia da razão. Rio de Janeiro: Relume Dumará, 1999. p.135-157.

ROSE, Nikolas. Como se deve fazer a história do eu. Educação e Realidade, v. 26, n. 1, p. 3357, jan./jul. 2001.

ROSE, Nikolas. A política da própria vida: biomedicina, poder e subjetividade no Século XXI. São Paulo: Paulus, 2013.

SARTI, Graciela, C. El mito de la vida artificial en la literatura y el cine. Buenos Aires: Editorial de la Faculdad de Filosofía y Letras UBA, 2012.

SHELLEY, Mary. Frankenstein: o Prometeu moderno. Porto Alegre: L\&PM, 1999.

SIBILIA, Paula. O homem pós-orgânico: corpo, subjetividade e tecnologias digitais. 2. ed. Rio de Janeiro: Relume Dumará, 2002.

VALLEJO, Gustavo; MIRANDA, Marisa. Apresentação: cuerpo social y cuerpo individual. In: VALLEJO, Gustavo; MIRANDA, Marisa (comp.). Políticas del cuerpo: estrategias modernas de normalización del indivíduo y la sociedad. Buenos Aires: Siglo XXI, 2007. p. 15-22.

ZOBOLI, Fabio. Educação do corpo e política. In: RODRIGUES, Ana Cláudia da Silva; SEVERO, José Leonardo Rolim de Lima. Diálogos interdisciplinares e temas emergentes na produção do conhecimento em Educação. João Pessoa: Editora do CCTA, 2018. p.365-374. 